\title{
Effects of Cylindrospermopsis raciborskii strains (Woloszynska, 1912) Senayya \& Subba Raju on the mobility of Daphnia laevis (Cladocera, Daphniidae)
}

\author{
Restani, GC.* and Fonseca, AL. \\ Institute of Natural Resources, Federal University of Itajubá - UNIFEI, Av. BPS, 1303, Pinherinho, CEP 37500-903, \\ Itajubá, MG, Brazil \\ *e-mail: geocoura@yahoo.com.br
}

Received: June 6, 2012 - Accepted: November 20, 2012 - Distributed: February 28, 2014

(With 1 figure)

\begin{abstract}
Cylindrospermopsis raciborskii is a cyanobacterium distributed worldwide that is known to produce cyanotoxins. Some of the Brazilian strains can produce saxitoxins (STXs), which are classified as neurotoxins and can paralyze cladocerans .Daphnia laevis is a cladoceran with a wide distribution in the Americas and has been studied as a possible test-organism in toxicity bioassays. The present work tested the acute effect on $D$ laevis mobility when fed a saxitoxin-producing (STX and neoSTX) C. raciborskii strain, CYRF-01, and compared the results with the effects of a non-toxic strain (NPCS-1). Neonates (6-24 hours after birth) were exposed to concentrations of C. raciborskii varying from $10^{2}$ to $10^{6}$ cells $\cdot \mathrm{mL}^{-1}$ of each strain for up to three hours. The cladocerans were then transferred to a medium without toxic filaments for 24 hours. Only the organisms exposed to the STX-producing strain showed signs of the immobilization of swimming movements, confirming the effects of the toxins. There was a linear correlation between the time required to induce stopping the swimming movement, with a shorter time to needed to induce immobilization at a higher the concentration; this correlation was inverse to the time required to recover the swimming movements (longer at higher concentrations, $\mathrm{p}<0.1$ ). D. laevis is a tropical and subtropical species with great potential for use in toxicity tests for the detection of STXs, despite being native to and found in a great array of freshwater bodies. This is the first assay testing STX-producing and non-producing C. raciborskii strains on D. laevis, species that are both found in Brazilian ecosystems.
\end{abstract}

Keywords: cyanobacteria, saxitoxin, Cladocera.

\section{Efeitos de cepas de Cylindrospermopsis raciborskii (Woloszynska, 1912), Senayya \& Subba Raju na mobilidade de Daphnia laevis (Cladocera, Daphniidae)}

\begin{abstract}
Resumo
Cylindrospermopsis raciborskii é uma espécie de cianobactéria, difundida mundialmente, conhecida como produtora de cianotoxinas. Algumas linhagens brasileiras são conhecidas como produtoras de saxitoxinas (STXs), as quais são classificadas como neurotoxinas e podem induzir a paralização dos movimentos natatórios em cladóceros. Daphnia laevis é um cladócero de ampla distribuição nas Américas e tem sido estudado como um organismo teste para uso em ensaios de toxicidade. Neste sentido, o presente trabalho avaliou os efeitos agudos de C. raciborskii, de uma cepa produtora de STXs (STX e neoSTX) - CYRF-01 e outra não produtora de cianotoxinas (NPCS-1) sobre a mobilidade de D. laevis. Para tanto, neonatas entre 6-24 horas de idade foram submetidas a concentrações de $C$. raciborskii variando de $10^{2}$ a $10^{6}$ céls. $\mathrm{mL}^{-1}$ de ambas as cepas, por um período de 3 horas, e transferidos posteriormente para um meio isento de filamentos tóxicos por 24 horas. Apenas os organismos expostos à cepa produtora de STXs apresentaram paralisia dos movimentos natatórios, confirmando o efeito da cianotoxina. Houve uma correlação linear entre o tempo de paralização e as concentrações, isto é, nas concentrações mais altas, os organismos paralisaram num curto período de tempo, e conseqüentemente, levaram mais tempo para se recuperar $(\mathrm{p}<0,1)$. D.laevis é uma espécie de região tropical e subtropical com potencial uso em bioensaios para detecção de STXs. Trata-se dos primeiros relatos acerca da resposta de D.laevis quando submetida às cepas de C. raciborskii produtora e não produtora de STXs, ambas isoladas de ecossistemas brasileiros.
\end{abstract}

Palavras-chave: cianobactérias, saxitoxinas, Cladocera. 


\section{Introduction}

Blooms of cyanobacteria are generally associated with the eutrophication of freshwater bodies (Sigee, 2005). According to Kaebernick and Neilan (2001), cyanotoxins are classified according to their toxicity in animals due to dermatotoxins (lyngbyatoxins and aplysiatoxins), hepatotoxins (cylindrospermopsins [CYNs], microcystins [MCYSTs] and nodularins [NODs]) and neurotoxins (saxitoxins [STXs] and anatoxins [ANTs]).

Saxitoxins are also known as paralytic shellfish toxins (PSTs) or poisons (PSPs) (Zagatto et al., 2012). These alkaloids are a group of neurotoxin carbamates that inhibit the propagation of nerve impulses in mammals through the blockage of sodium channels, which causes neuromuscular paralysis (Chorus and Bartram, 1999). According to Oshima (1995), there are 30 saxitoxin analogs in this group, with differences in toxicity and time course of action, including N-1 hydroxysaxitoxin or neosaxitoxin (neoSTX), the 11-sulfate analogs of STX and neoSTX called gonyautoxins (GTX) and the 6 N21 sulfo derivatives of STX, neoSTX and GTX toxins B1, B2 and C1 to C4 (Mahmood and Carmichael 1986; Chorus and Bartram 1999).

The cyanobacteria reported in the literature able to produce STXs are as follows: Anabaena circinalis and Aphanizomenon. (Chorus and Bartram, 1999); Anabaena lemmermannii (Kaas and Henriksen, 2000); Cylindrospermopsis raciborskii (Lagos et al., 1999); Lyngbya wollei (Chorus and Bartram, 1999; Carmichael et al., 1997) and Planktothrix (Pomati et al., 2000). C. raciborskii has been considered an invasive species (Jardim and Azevedo, 2006), and blooms have been reported in several countries, with toxic strains being reported to produce cylindrospermopsin. Strains of C. raciborskii have also been reported to produce saxitoxins in Brazilian waters (Lagos et al., 1999; Molica et al., 2002; Ferrão-Filho et al., 2007).

According to Ferrão-Filho and Kozlowsky-Suzuki (2011), there are few studies showing the effects of saxitoxins on freshwater zooplankton species. Among other reports, Haney et al. (1995) exposed Daphnia carinata to both filtered culture and purified STX produced by Aphanizomenon flos-aquae. Nogueira et al. (2004) administered purified saxitoxins produced by Aphanizomenon issatschenkoi to the cladoceran Daphnia magna, whereas Soares et al. (2009b) exposed D. magna to an STX-producing strain (CYRF-01).

The inhibition of swimming movements in aquatic organisms is a common effect of STXs. Lefebvre et al. (2005) exposed the fish species Clupea harengus pallasi to STX and observed that these animals showed a reduction in their spontaneous swimming response; however, the animals recovered their swimming ability after four to 24 hours of continuous exposure.

Similarly, studies using the cladoceran Daphnia pulex have demonstrated that the presence of STXs compromise the swimming ability evaluated by the average distance travelled and average speed (Ferrão-Filho et al., 2007). Later, Ferrão-Filho et al. (2010) conducted a series of bioassays exposing $D$. pulex and Moina micrura to the neurotoxic C. raciborskii strain CYRF-01 for three hours and reported that these animals are able to recover their swimming ability after being transferred to a vial without toxic filaments. These authors emphasize the importance of bioassays testing the toxicity of cyanotoxins using a greater number of tropical and subtropical species. Eventually, a standardization of the procedures will translate into a higher correlation between environmental conditions and the bioassays, providing us with better prediction tools.

Daphnia laevis is widely distributed in all of the Americas (Matsumura-Tundisi, 1984) and has been investigated for its potential as a test-organism in ecotoxicological bioassays (Fonseca and Rietzler, in prep.). The species would make a better option than the usual "non-native" organisms by conferring a greater ecological relevance to the studies because a native species is more effectively able to represent the local environmental conditions. This would guarantee more reliability and a direct interpretation of the results.

To this end, we tested the effects of C. raciborskii strains that are producers and non-producers of STXs (STX and neoSTX) isolated from tropical ecosystems on the mobility of $D$. laevis. The results presented here constitute the first report of the response of $D$. laevis when exposed to these toxins.

\section{Material and Methods}

\subsection{Organisms}

The STX-producing strain of C. raciborskii (CYRF-01) was originally isolated from Funil reservoir (Resende, Rio de Janeiro State - Brazil - 22 31 ' 42” S, 4433' 49” W). The strain that does not produce STXs, herein NPCS-1, was isolated from Custódia reservoir (Custódia, Pernambuco State - Brazil - $08^{\circ} 05^{\prime} 15^{\prime}$ ' S, $37^{\circ} 38^{\prime} 35^{\prime}$ ' W).

Both strains were kindly provided by the Laboratory of Ecophysiology and Toxicology of Cyanobacteria (LETC, Federal University of Rio de Janeiro, Rio de Janeiro Brazil) and maintained in the Ecotoxicology Laboratory of the Federal University of Itajubá (Itajubá, Minas Gerais State - Brazil). The production or "non-production" of saxitoxins is commonly confirmed by high performance liquid chromatography - HPLC for both strains.

Two cultures of each strain (CYRF-01 and NPCS-1) were grown in ASM-1 medium (Gorham et al., 1964) with the $\mathrm{pH}$ adjusted to 7.5 , continuous aeration, a temperature of $24 \pm 2{ }^{\circ} \mathrm{C}$ and light intensity of $26 \mu$ moles photons. $\mathrm{m}^{-2} \cdot \mathrm{s}^{-1}$. The medium was replaced every four days for each culture to maintain them in an exponential growth phase, and the samples for testing were collected at the time of replacement. The cell density counts of both strains were performed using a Fuchs-Rosenthal hemocytometer.

The initial $D$. laevis specimens were isolated from Lagoa da Pampulha (Belo Horizonte, Minas Gerais - Brazil) and provided by the Biology Institute (Universidade Federal de Minas Gerais, Belo Horizonte, Brazil). These organisms were maintained in ground water, with the $\mathrm{pH}$ adjusted to 
7.4 and an average hardness of $34 \mathrm{mg} \cdot \mathrm{L}^{-1} \mathrm{CaCO}_{3}$, and kept in an incubator with a photoperiod of $12 / 12 \mathrm{~h}$ light/dark and a temperature of $23 \pm 2{ }^{\circ} \mathrm{C}$. The animals were fed daily with Pseudokirchneriella subcapitata at a concentration of $10^{5}$ - cells $\cdot \mathrm{mL}^{-1}$ cultivated in Oligo medium according to NBR 12713 (ABNT, 2009).

\subsection{Quantification of saxitoxins (STXS) and neosaxitoxins (neoSTXs)}

The quantification of STX and neoSTX in the cell extract (CYRF-01) was assessed using HPLC following the methods described by Oshima (1995) in collaboration with Laboratory of Ecophysiology and Toxicology of Cyanobacteria (LETC, Federal University of Rio de Janeiro, Rio de Janeiro - Brazil).

Before lyophilization, the samples were frozen and thawed to guarantee proper cell lysis. For the extraction of toxins, $5 \mathrm{~mL} 500 \mathrm{mM}$ acetic acid was added to the lyophilized material, and the solution was subjected to magnetic stirring for $2 \mathrm{~h}$ and then centrifuged for $30 \mathrm{~min}$ at $10,000 \mathrm{rpm}$. The procedure was repeated twice, and the supernatants were combined and filtered through nylon filters (Millipore) of $0.45 \mu$ and $13 \mathrm{~mm}$ diameter.

STX and neoSTX were analyzed using a Shimadzu HPLC system with an orthosilicate or C18 silica reversedphase column $(125 \mathrm{~mm} \times 4.0 \mathrm{~mm}, 5 \mathrm{~mm}$; Lichrospher 100RP 18). The chromatographic conditions were as follow: mobile phase of $2 \mathrm{mM}$ heptanesulfonate in $30 \mathrm{mM}$ ammonium phosphate and 6\% acetonitrile, $\mathrm{pH} 7.1$ (flow rate of $1 \mathrm{~mL} . \mathrm{min}$ ). The toxins were detected using a fluorometric detector, with excitation wavelength at $330 \mathrm{~nm}$ and emission at $390 \mathrm{~nm}$. The toxins were identified and quantified by comparison with the retention time and integrated areas acquired from commercial standards. The standards were purchased from the Institute of Marine Bioscience, National Research Council of Canada (Halifax, Canada).

\subsection{Acute toxicity bioassay}

The methodology used follows that proposed by Ferrão-Filho et al. (2010), with five repetitions aiming to detect the effects of neurotoxins in D. laevis. Only intact cells of C. raciborskii were used, and this methodology consists of two distinct phases.
Exposure phase: In this phase, D. laevis neonates, ages varying from 6 to 24 hours after birth, according to the recommendations proposed by NBR 12713 (ABNT, 2009), were exposed to different densities of $C$. raciborskii strains CYRF-01 and NPCS- 1 at concentrations of $10^{2}$, $10^{3}, 10^{4}, 10^{5}$ and $10^{6}$ cells. $\mathrm{mL}^{-1}$, in addition to the control solution (water in which the animals were maintained). For each of the treatments (concentrations), 10 neonates were kept in Erlenmeyer flasks with $20 \mathrm{~mL}$ of algal suspension in three replicates. The mobility of the $D$. laevis individuals was evaluated after 30 minutes and 1,2 and 3 hours of exposure by counting the immobilized and dead individuals.

Recuperation phase: At three hours after being exposed to the treatment, all of the organisms (that is also true for control treatment) were transferred to new solutions with only cultivation medium and $P$. subcapitata at a concentration of $10^{6}$ cells. $\mathrm{mL}^{-1}$. The mobility of the individuals was observed at 15 and 24 hours after exposure. At the end of this phase, the number of animals that showed no signs of difficulty in swimming or were immobilized or dead was counted.

\subsection{Statistical analysis}

An exponential regression model was utilized for the stage of exposure, with the STX concentration as the dependent variable and the immobilization time of Daphnia as the independent variable. The same model was performed for the recovery phase using the STX concentration as the dependent variable and the recovery time of organisms as the independent variable. To achieve this adjustment, we used Statistica version 7.0 (Statsoft, 2007). The actual time for the immobilization of $50 \%$ of the individuals $\left(\mathrm{ET}_{50}\right)$ was calculated using the tool analysis 'probit' of SPSS 8.0 (Statistical Package, 1997).

\section{Results}

The concentrations in the tested solutions were estimated from the quantification of STX and neoSTX in the cell extract (Table 1). The results showed that all of the neonates of $D$. laevis at the highest concentration of STX and neoSTX were immobilized after 30 minutes of exposure (Figure 1). Similarly, all of the organisms exposed to concentrations of $10^{4}$ to $10^{5}$ cells. $\mathrm{mL}^{-1}$ (see the STX concentrations in Table 1) were immobilized in a period

Table 1. Concentration of saxitoxins (STXs) and neosaxitoxins (neoSTXs) detected in C. raciborskii (CYRF-01) strains for bioassays with $D$. laevis.

\begin{tabular}{|c|c|c|c|}
\hline \multirow{3}{*}{$\begin{array}{c}\text { Concentration CYRF } \\
\left(\text { cells.mL } L^{-1}\right)\end{array}$} & \multicolumn{3}{|c|}{ Concentrations of neurotoxins (ng.EqSTX.L ${ }^{-1}$ ) } \\
\hline & STX & & \\
\hline & Bioassays 1,2,3,4 e 5 & $\begin{array}{c}\text { Bioassay } \\
1 \\
\end{array}$ & $\begin{array}{c}\text { Bioassays } \\
2,3,4 \text { e } 5\end{array}$ \\
\hline $10^{6}$ & 14 & 12 & 55 \\
\hline $10^{5}$ & 1.4 & 1.2 & 0.55 \\
\hline $10^{4}$ & 0.14 & 0.12 & 0.055 \\
\hline $10^{3}$ & 0.014 & 0.012 & 0.0055 \\
\hline $10^{2}$ & 0.0014 & 0.0012 & 0.00055 \\
\hline
\end{tabular}



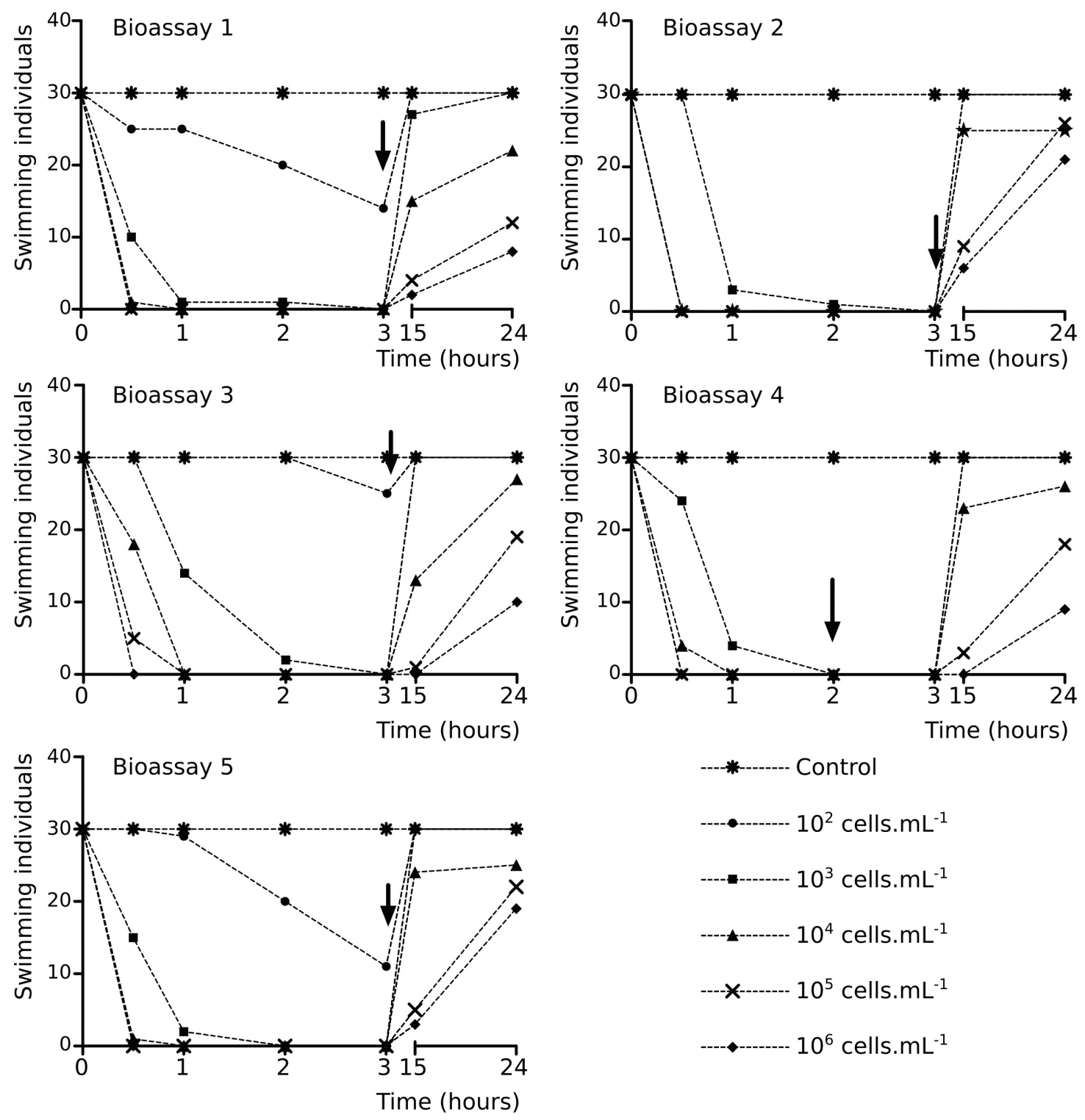

Figure 1. Gross results of acute bioassays with D. laevis exposed to different cellular concentrations CYRF- 01 strain. These consisted of two phases: exposure phase - when cladocerans were exposed by 3 hours at a range of concentrations of CYRF-01; and recovery phase - when the cladocerans were exposed to P.subcapitata (concentration of $10^{6}$ cells. $\mathrm{mL}^{-1}$ by 15 and 24 hours. The control treatment consisted of only water cultivation (stage of exposure) and $P$. subcapitata (recovery phase). The arrows indicate the time that was a greater number of paralyses.

shorter than three hours (Figure 1). The neonates exposed to lower concentrations $\left(10^{2}\right.$ to $10^{3}$ cells. $\mathrm{mL}^{-1}$; Table 1$)$ showed a higher variation in their immobilization response. In contrast, the $D$. laevis exposed to $C$. raciborskii that do not produce STXs and the control (exposed to culture medium) retained their ability to swim during the entire exposure period. These results were confirmed by the statistical analysis, as shown by the regression equation in Table 2, whereby earlier immobilization and a longer recovery time occur with a higher concentration.

The recovery phase (organisms were exposed to only culture water and food) corroborate the results obtained in the exposure phase, that is, recovery requires a longer period of time for animals exposed to higher concentrations (Figure 1). The recovery results were tested and confirmed statistically (Table 2).

The values for the effective time of immobilization of $50 \%$ of the organisms $\left(\mathrm{ET}_{50}\right)$ corroborate the untreated results, and we can predict a stabilization of the time required for the immobilization response at higher concentrations (Table 3). It is irrefutable that toxins at concentrations higher than $10^{4}$ cells. $\mathrm{mL}^{-1}$ produced similar results $\left(\mathrm{ET}_{50}\right)$, indicating that $10^{4}$ cells. $\mathrm{mL}^{-1}$ is the minimum concentration required to induce a saturation response by $D$. laevis. 
Table 2. Regression equations of the concentration of STX (ng.EqSTX.L ${ }^{-1}$ ), (y) against exposure and recovery time, hours, (x) in different days of evaluation using $D$. laevis as a test-organism.

\begin{tabular}{|c|c|c|c|}
\hline \multicolumn{4}{|c|}{ EXPOSURE TIME (Immobilized Organisms) } \\
\hline Time (hours) & Equation & $\mathbf{r}^{2}$ & $S_{y x}$ \\
\hline \multicolumn{4}{|c|}{ Bioassay 1} \\
\hline 0.5 & 20.62053.exp(18.639.X)* & 0.414 & 0.17154178 \\
\hline 1 & 23.19218.exp $(10.57982 . X)^{*}$ & 0.294 & 0.08646951 \\
\hline 2 & 24.48933.exp $(8.38500 . X)^{*}$ & 0.298 & 0.08902688 \\
\hline 3 & 26.31517.exp(5.45519.X)* & 0.282 & 0.07959302 \\
\hline \multicolumn{4}{|c|}{ Bioassay 2} \\
\hline 0.5 & 14.56997.exp $(38.37920 . X)^{\mathrm{ns}}$ & 0.446 & 0.19935482 \\
\hline 1 & 21.38739.exp $(18.41823 . \mathrm{X})^{*}$ & 0.313 & 0.09803405 \\
\hline 2 & $21.90147 . \exp (17.16027 . \mathrm{X})^{*}$ & 0.291 & 0.08460629 \\
\hline 3 & 22.15892.exp $(16.54003 . \mathrm{X})^{*}$ & 0.279 & 0.07811658 \\
\hline \multicolumn{4}{|c|}{ Bioassay 3} \\
\hline 0.5 & 8.99118.exp(62.64017.X $)^{\mathrm{ns}}$ & 0.702 & 0.49326256 \\
\hline 1 & 18.58039.exp(25.80457.X)* & 0.409 & 0.16731020 \\
\hline 2 & $21.64430 . \exp (17.78629 . \mathrm{X})^{*}$ & 0.302 & 0.09125884 \\
\hline 3 & 23.45092.exp(13.51301.X)* & 0.280 & 0.07858988 \\
\hline \multicolumn{4}{|c|}{ Bioassay 4} \\
\hline 0.5 & 15.06849.exp $(36.6093 . X)^{\mathrm{ns}}$ & 0.495 & 0.24511170 \\
\hline 1 & 21.13076.exp $(19.05622 . \mathrm{X})^{*}$ & 0.324 & 0.10488794 \\
\hline 2 & $22.15892 . \exp (16.54003 . \mathrm{X}) *$ & 0.279 & 0.07811658 \\
\hline 3 & 22.15892.exp $(16.54003 . X)^{*}$ & 0.279 & 0.07811658 \\
\hline \multicolumn{4}{|c|}{ Bioassay 5} \\
\hline 0.5 & 18.07516.exp(27.2306.X)* & 0.428 & 0.18364957 \\
\hline 1 & 23.45128.exp $(13.50989 . X)^{*}$ & 0.310 & 0.09625661 \\
\hline 2 & 24.74929.exp $(10.61046 . X)^{*}$ & 0.281 & 0.07905193 \\
\hline 3 & 24.74929.exp $(10.61046 . X)^{*}$ & 0.281 & 0.07905193 \\
\hline
\end{tabular}

\section{RECOVERY TIME (Mobile Organisms)}

\begin{tabular}{|c|c|c|c|}
\hline \multicolumn{4}{|c|}{ Bioassay 1} \\
\hline 15 & 29.60.exp $(-2620.47 . X)^{*}$ & 0.984 & 0.96876809 \\
\hline 24 & 32.16.exp $(-5497.83 . X)^{*}$ & 0.911 & 0.83055550 \\
\hline \multicolumn{4}{|c|}{ Bioassay 2} \\
\hline 15 & 29.696.exp $(-632.791 . X)^{*}$ & 0.964 & 0.29435850 \\
\hline 24 & 28.0256.exp $(-15.2754 . X)^{*}$ & 0.828 & 0.68575704 \\
\hline \multicolumn{4}{|c|}{ Bioassay 3} \\
\hline 15 & 31.32.exp $(-4411.45 . X)^{*}$ & 0.997 & 0.99571447 \\
\hline 24 & $27.6480 . \exp (-61.2346 . X)^{*}$ & 0.922 & 0.85066640 \\
\hline \multicolumn{4}{|c|}{ Bioassay 4} \\
\hline 15 & 30.20.exp $(-1271.12 . X)^{*}$ & 0.999 & 0.99901010 \\
\hline 24 & 27.2857.exp $(-69.7862 . X)^{*}$ & 0.914 & 0.83614486 \\
\hline \multicolumn{4}{|c|}{ Bioassay 5} \\
\hline 15 & 29.983.exp $(-963.754 . X)^{*}$ & 0.992 & 0.98573629 \\
\hline 24 & 27.1856.exp $(-20.0594 . x)^{*}$ & 0.775 & 0.60155591 \\
\hline
\end{tabular}

ns - without statistical significance; * with statistical significance $(\mathrm{p}<0,1) ; \mathrm{r}^{2}$ - determination coefficient adjusted; $\mathrm{S}_{\mathrm{yx}}$ - standard deviation of the estimative.

The mortality rate during the entire assay ( 24 hours) was extremely low; it was zero for four of the tested conditions and only $3.33 \%$ for one of the replicates exposed to $10^{4}$ cells. $\mathrm{mL}^{-1}$ of the CYRF strain.

In relation to the concentrations in the tested solutions of STX and neoSTX, there was a difference in the production of neoSTX between the two cultures of CYRF used in the bioassays (number 1 and remaining assays - Table 1). Although the light intensity had been controlled, this variable may have influenced the production of STXs. However, the $\mathrm{r}^{2}$ values (Table 1) were not significantly different for the different bioassays. 
Table 3. $\mathrm{ET}_{50}$ values (time, in hours, of immobilization of $50 \%$ of the organisms) for D. laevis exposed to a strain of $C$. raciborskii producer STXs (CYRF).

\begin{tabular}{cccccc}
\hline \multirow{2}{*}{ Acute Bioassay } & \multicolumn{5}{c}{ Concentrations (cells.mL } \\
\cline { 2 - 6 } & $\mathbf{1 0}^{-1}$ ) & $\mathbf{1 0}^{5}$ & $\mathbf{1 0}^{6}$ \\
\hline 1 & 2.76 & 0.47 & $0.29(0.19-0.38)$ & $0.28(0.17-0.37)$ & $0.28(0.17-0.37)$ \\
2 & $\mathrm{NE}$ & 0.86 & $0.51(0.42-0.61)$ & $0.28(0.17-0.37)$ & $0.28(0.17-0.37)$ \\
3 & 3.41 & $1.14(0.99-1.32)$ & $0.54(0.45-0.64)$ & $0.28(0.17-0.37)$ & $0.28(0.17-0.37)$ \\
4 & $\mathrm{NE}$ & $0.71(0.61-0.81)$ & $0.34(0.23-0.42)$ & $0.28(0.17-0.37)$ & $0.28(0.17-0.37)$ \\
5 & $2.58(2.30-2.95)$ & $0.54(0.43-0.64)$ & $0.29(0.19-0.38)$ & $0.28(0.17-0.37)$ & $0.28(0.17-0.37)$ \\
\hline
\end{tabular}

NE - not estimated.

\section{Discussion}

Blooms of C. raciborskii that can produce STXs have often been reported by different authors for Brazilian water bodies (Lagos et al., 1999; Tucci and Sant'Anna, 2003; Yunes et al., 2000, 2003; Molica et al., 2005; Ferrão-Filho et al., 2009; Moschini-Carlos et al., 2009; Aragão, 2011). The frequency of such reports call attention to the possible side-effects of these blooms; of common concern is the effects that the blooms might have on aquatic biota and human health (with regard to drinking water).

The mandatory Brazilian legislation 2.914/11 (Brasil, 2011) considers that cyanobacterial monitoring should be weekly at 10,000 cells. $\mathrm{mL}^{-1}$ and that cyanotoxin monitoring at 20,000 cells. $\mathrm{mL}^{-1}$ should be on a weekly basis. Although this ordinance refers to the supply and standards of drinking water for human consumption, the values of the cell densities used indicate the conditions of Brazilian ecosystem blooms. Thus, the values of the cell densities of cyanobacteria proposed by this legislation served as a guideline for the concentrations used for the bioassays in this work because the term "bloom" is not well defined and is generally described as being a phytoplankton biomass significantly higher than the average of the water body in question (Zohary and Roberts, 1990).

There are still only a few scattered studies on the effects of STXs on freshwater aquatic biota when compared with other cyanotoxins (MCYST, for example), but its potential for causing serious damage has been tested in many species (Landsberg, 2002). Clemente et al. (2010) reported that STX (in GTX form) bio-accumulated in the muscles of the fish species Geophagus brasiliensis collected in a Brazilian reservoir with blooms and predominance of C. raciborskii. These authors described some of histopathological alterations and attributed them to other chemical compounds found in the water of the reservoir.

Haney et al. (1995) described a reduction of the movement of the thoracic appendages and an increase of the rejection of particles retained in the post-abdomen of Daphnia carinata when exposed to a filtrate of Aphanizomenon flosaquae that produces STX, similar to the results obtained when these animals were exposed to purified STX. Nogueira et al. (2004) observed negative effects on the growth, survival and accumulation of STXs produced by Aphanizomenon issatschenkoi in D. magna. The above-mentioned effects indicate that the survival of these organisms might be challenged by repeated cyanobacterial blooms that are able to produce STXs.

Our results strongly suggest that the immobilization of D. laevis exposed to the STX-producing strain was caused by these cyanotoxins because a strain that does not produce STXs caused no effect on the mobility of this cladoceran. Furthermore, the concentration of the toxins had a significant correlation with time required to immobilize the animals, which corroborates this hypothesis. The results presented here are in accordance with the results presented by FerrãoFilho et al. (2010) with Daphnia pulex and Moina micrura exposed to the same cyanotoxin, emphasizing that other Daphnia species may be threatened by these cyanotoxins in the environment.

The small variations in the paralysis response of D. laevis in the presence of low concentrations of STXs can be explained by the fact that the specimens used originated from several different cultures of $D$. laevis maintained in the laboratory to provide us newborns for the bioassays. In this sense, Hietala et al. (1995, 1997) and Laurén-Määttä et al. (1997) found different results in the survival, growth and reproduction of different clones of Daphnia exposed to an MCYST-producing strain of Microcystis aeruginosa.

The $\mathrm{ET}_{50}$ values obtained in the present study show a clear stabilization over time of the immobilization response of $D$. laevis when exposed to higher concentrations of an STX-producing strain of $C$. raciborskii. The present study corroborates the studies of Ferrão-Filho et al. (2010) for D. pulex and M. micrura, reporting a linear response of the tested organisms to the concentrations of STXs that varied from $0.3 \mathrm{ng}$.EqSTX.L ${ }^{-1}$ to $3.0 \mathrm{ng}$.EqSTX.L ${ }^{-1}$ and a stabilization of the response at higher concentrations without a decrease in the $\mathrm{ET}_{50}$. The regression equations confirm these findings by the estimates of the adjusted regression determination coefficient $\left(\mathrm{r}^{2}\right)$ and (Syx) (standard deviation of the estimate) in which, despite the low values, correctly explain the relationship between the concentration of STX and the exposure time or recovery time.

According to Ferrão-Filho et al. (2010), the linearly transformed data reflect a saturation of the response of the absorption of the STXs through bioaccumulation, and the effects suffered take equally long after a certain concentration of toxin. This response was also observed in the present study and most likely reflects a saturation 
of the target site of saxitoxins (i.e., $\mathrm{Na}^{+}$channels). Thus, our results strongly corroborate those of Ferrão-Filho et al. (2010), confirming that organisms may be rapidly immobilized when exposed to STXs during toxic blooms. However, as soon as the concentration of toxic cells decreases (e.g., after bloom decay), the animals can recover their swimming ability. Ferrão-Filho et al. (2008) reported that the recovery depends on the species tested, density of toxic filaments in the water and time of exposure. The dependency of these factors with regard to the recuperation of cladocerans might complicate their survival in natural ecosystems. Havens (2008) described that the temporal dynamics of cyanobacteria blooms are variable, lasting longer in certain systems and occurring sporadically in others. The composition of zooplankton, therefore, might suffer permanent alterations when toxic blooms are more prevalent.

Ferrão-Filho et al. (2009) detected that more than $90 \%$ of the phytoplankton community of Funil reservoir (CYRF-01 occurrence reservoir) was composed of cyanobacteria during most of the monitored period (March/2002 to June/2006). During this period, the diversity of phytoplankton and, accordingly, the diversity of the larger cladocerans were greatly reduced, particularly in 2004 when cyanobacterial blooms became more prevalent (Soares et al., 2009a).

The STX concentrations in natural ecosystems can vary considerably. Ferrão-Filho et al. (2010) reported seston concentrations varying from $0.3 \mathrm{ng}$.EqSTX.L $\mathrm{L}^{-1}$ to 3480 ng.EqSTX.L ${ }^{-1}$ (STX, neoSTX and GTX-1, -2 and -4) for Funil reservoir (Resende, Rio de Janeiro State). Clemente et al. (2010) reported different seasonal concentrations of STXs for Alagados reservoir (Ponta Grossa, Paraná State), varying from $5.15 \mathrm{ng}$.EqSTX.L $\mathrm{L}^{-1}$ (GTX-2, -3 and -5$)$ in the spring to 43.8 ng.EqSTX.L ${ }^{-1}$ (GTX-2, $-3,-4$ and -5 ) in the summer and to $5070 \mathrm{ng}$.EqSTX.L ${ }^{-1}$ (GTX-2, -3, -4 and -5) in the autumn. Molica et al. (2005) reported concentrations of $52 \mathrm{ng} . \mathrm{L}^{-1}$ of STX and $5.1 \mathrm{ng} . \mathrm{L}^{-1}$ of neoSTX in a water sample of the Tapacurá reservoir (Recife, Pernambuco State) in the period from the end of March until May 2002. Based on the reports above, we can state that the bioassays performed in the present work for the concentrations of STXs were compatible with the concentrations reported in the natural environment, and we showed that these concentrations affect $D$. laevis.

D. laevis was shown to be sensitive to the presence of STXs in a way that its survival in environments with regular blooms of cyanobacteria would be compromised, particularly if these blooms persist for long periods. The fact that this native species is sensitive to STXs emphasizes the need for further studies aiming at a standardization of this species in toxicity tests for STX-producing strains of cyanobacteria and raw water samples from eutrophic environments.

Acknowledgements - The authors would like to thank to Dr. Arnola Rietzler, UFMG for the clones of Daphnia laevis, Dr. Sandra M.F.O. Azevedo, UFRJ, for the Cylindrospermopsis raciborskii strains and quantifications of STX and neoSTX,
Dr. Fabrina Martins Bozan, UNIFEI, for the help with the statistical analysis, Dr. Humberto F. Mendes helped with the language in an earlier version of the manuscript. Thanks are also due to Aloysio S. Ferrão-Filho for critics and suggestions in an earlier version of this article. The authors received financial grants from FAPEMIG CRAAPQ-00638-08.

\section{References}

Associação Brasileira de Normas Técnicas - ABNT. NBR 12713:2009: Ecotoxicologia Aquática -Toxicidade aguda - Método de ensaio com Daphnia spp. (Cladocera, Crustacea). Rio de Janeiro: ABNT. 23 p.

ARAGÃO, NKCV., 2011. Taxonomia, distribuição e quantificação de populações de cianobactérias em reservatórios do estado de Pernambuco (Nordeste do Brasil). Pernambuco: Universidade Federal Rural de Pernambuco. 157 p. Dissertação de Mestrado em Botânica. Available from: <http://www.pgb.ufrpe.br/doctos/2011/ dissertacoes $/>$.

BRASIL. Ministério da Saúde, 2011. Portaria 2.914, de 12 de dezembro de 2011. Dispõe sobre os procedimentos de controle e de vigilância da qualidade da água para consumo humano e seu padrão de potabilidade. Diário Oficial da República Federativa do Brasil, Brasília, dez. 18 p. Available from: <http://bvsms. saude.gov.br/bvs/saudelegis/gm/2011/prt2914_12_12_2011.html >.

CARMICHAEL, WW., EVANS, WR., YIN, QQ., BELL, P. and MOCZYDLOWSKI, E., 1997. Evidence for paralytic shellfish poisons in the freshwater cyanobacterium Lyngbya wollei (Farlow ex Gomont) comb. Nov. Applied and Environmental Microbiology, vol. 63, p. 3104-3110. PMid:9251196 PMCid:PMC168607.

CHORUS, I. and BARTRAM, J. (Ed.), 1999. Toxic cyanobacteria in water: A guide to public health consequences, monitoring and management. London and New York: World Health Organization. 416\#@p. http://dx.doi.org/10.4324/9780203478073

CLEMENTE, Z., BUSATO, RH., RIBEIRO, CAO., CESTARI, MM., RAMSDORF, WA., MAGALHÃES, VF., WOSIACK, AC. and ASSIS, HCS., 2010. Analyses of paralytic shellfish toxins and biomarkers in a southern Brazilian reservoir. Toxicon, vol. 55, p. 396-406. PMid:19778550. http://dx.doi.org/10.1016/j. toxicon.2009.09.003

FERRÃO-FILHO, AS., SOARES, MCS., MAGALHÃES, VF. and AZEVEDO, SMFO., 2009. Biomonitoring of cyanotoxins in two tropical reservoirs by cladoceran toxicity bioassays. Ecotoxicology. Environmental Safety, vol. 72, 479-489. PMid:18407352. http:// dx.doi.org/10.1016/j.ecoenv.2008.02.002

-, 2010. A rapid bioassay for detecting saxitoxins using a Daphnia acute toxicity test. Environmental Pollution, vol. 158, p. 2084-2093. PMid:20359802. http://dx.doi.org/10.1016/j.envpol.2010.03.007

FERRÃO-FILHO, AS., COSTA, SM., RIBEIRO, MGL. and AZEVEDO, SMFO., 2008. Effects of a saxitoxin-producer strain of Cylindrospermopsis raciborskii (Cyanobacteria) on the swimming movements of Cladocerans. Environmental Toxicology, vol. 23, p. 161-168. PMid:18214915. http://dx.doi.org/10.1002/tox.20320

FERRÃO-FILHO, AS., CUNHA, R., MAGALHÃES, VF., SOARES, MCS. and BAPTISTA, DF., 2007. Evaluation of sub-lethal toxicity of Cyanobacteria on the swimming activity of aquatic organisms by image analysis. Journal of the Brazilian Society of Ecotoxicology, vol. 2, no. 2, p. 1- 8. 
FERRÃO-FILHO, AS. and KOZLOWSKY-SUZUKI, B., 2011. Cyanotoxins: Bioaccumulation and effects on aquatic animals. Marine Drugs, vol. 9, p. 2729-2772. PMid:22363248 PMCid:PMC3280578. http://dx.doi.org/10.3390/md9122729

GORHAM, PR., MCLACHLAN, JR., HAMMER, VT. and KIM, WK., 1964. Isolation and culture of toxic strains of Anabaena flos-aquae (Lyngb.) de Bréb. Verhandlungen der internationale Vereinigung für theorestiche und angewandte Limnologie, vol. 15, p. 796-804.

HANEY, JF., SASNER, JJ. and IKAWA, M., 1995. Effects of products released by Aphanizomenon flos-aquae and purified saxitoxin on the movements of Daphnia carinata feeding appendages. Limnology and Oceanography, vol. 40, no. 2, p. 263-272. http://dx.doi.org/10.4319/1o.1995.40.2.0263

HAVENS, KE., 2008. Cyanobacteria Blooms: Effects on Aquatic Ecosystems. In HUDNELL, H. (Ed.). Cyanobacterial Harmful Algal Blooms: State of the Science and Research Needs. p. 733-747.

HIETALA, J., LAURÉN-MÄÄTTÄ, C. and WALLS, M., 1997. Life history responses of Daphnia clones to toxic Microcystis at different food levels. Journal of Plankton Research, vol. 19, no. 7, p. 917-926. http://dx.doi.org/10.1093/plankt/19.7.917

HIETALA, J., REINIKAINEN, M. and WALLS, M., 1995. Variation in life history responses of Daphnia to toxic Microcystis aeruginosa. Journal of Plankton Research, vol. 17, p. 2307-2318. http://dx.doi.org/10.1093/plankt/17.12.2307

JARDIM, FA. and AZEVEDO, SMFO., 2006. Cianobactérias em águas para abastecimento público e o cumprimento da Legislação Brasileira. Boletim da Sociedade Brasileira de Limnologia, vol. 35, no. 3, p. 86-91.

KAAS, H. and HENRIKSEN, P., 2000. Saxitoxins (PSP toxins) in Danish lakes. Water Research, vol. 34, no. 7, p. 2089-2097. http://dx.doi.org/10.1016/S0043-1354(99)00372-3

KAEBERNICK, M. and NEILAN, BA., 2001. Ecological and Molecular Investigations of Cyanotoxin production. FEMS. Microbiology Ecology, vol. 35, p. 1-9. PMid:11248384. http:// dx.doi.org/10.1111/j.1574-6941.2001.tb00782.x

LAGOS, N., ONODERA, H., ZAGATTO, PA., ADRINOLO, D., AZEVEDO, SMFO. and OSHIMA, Y., 1999. The first evidence of paralytic shellfish toxins in the freshwater cyanobacterium Cylindrospermopsis raciborskii, isolated from Brazil. Toxicon, vol. 37, p. 1359-1373. http://dx.doi.org/10.1016/S0041-0101(99)00080-X

LANDSBERG, JH., 2002. The effects of harmful algal blooms on aquatic organims. Reviews in Fisheries Science, vol. 10, no. 2, p. 113-390. http://dx.doi.org/10.1080/20026491051695

LAURÉN-MÄÄTTÄ, C., HIETALA, J. and WALLS, M., 1997. Responses of Daphnia pulex populations to toxic cyanobacteria. Freshwater Biology, vol. 37, p. 635-647. http://dx.doi.org/10.1046/ j.1365-2427.1997.00189.x

LEFEBVRE, KA., ELDER, NE., HERSHBERGER, PK., TRAINER, VL., STEHR, CM. and SCHOLZ, NL., 2005. Dissolved saxitoxin causes transient inhibition of sensorial motor function in larval Pacific herring (Clupea harengus pallasi). Marine Biology, vol. 147, p. 1393-1402. http://dx.doi.org/10.1007/s00227-005-0048-8

MATSUMURA-TUNDISI, T., 1984. Ocurrence of species of the genus Daphnia in Brazil. Hydrobiologia. vol. 112, p. 161-165. http://dx.doi.org/10.1007/BF00008082

MAHMOOD, NA., CARMICHAEL, WW., 1986. Paralytic shellfish poisons produced by the freshwater cyanobacterium
Aphanizomenon Flos-Aquae Nh-5. Toxicon, vol. 24, no. 480, p. 175-786. PMid:3085292.

MOLICA, RJR., OLIVEIRA, EJA., CARVALHO, PVVC., COSTA, APNSF., CUNHA, MCC., MELO, GL. and AZEVEDO, SMFO., 2005. Ocurrence of saxitoxins and an anatoxin-a(s)-like anticholinesterase in a Brazilian drinking water supply. Harmful Algae, vol. 4, p. 743-753. http://dx.doi.org/10.1016/j.hal.2004.11.001

MOLICA, RJR., ONODERA, H., GARCÍA, C., RIVAS, M., ANDRINOLO, D., NASCIMENTO, SM., MEGURO, H., OSHIMA, Y., AZEVEDO, SMFO. and LAGOS, N., 2002. Toxins in the freshwater cyanobacterium Cylindrospermopsis raciborskii (Cyanophyceae) isolated from Tabocas reservoir in Caruaru, Brazil, including demonstration of a new saxitoxin analogue. Phycologia, vol. 41, no. 6, p. 606-611. http://dx.doi.org/10.2216/ i0031-8884-41-6-606.1

MOSCHINI-CARLOS, V., BORTOLLI, S., PINTO, E., NISHIMURA, PY., FREITAS, LGD., POMPEO, MLM. and DOOR, F., 2009. Cyanobacteria and cyanotoxin in the Billings Reservoir (São Paulo, SP, Brazil). Limnetica, vol. 28, no. 2, p. 227-236.

NOGUEIRA, ICG., PEREIRA, P., DIAS, E., PFLUMACHER, S., WIEGAND, C., FRANCA, S. and VASCONCELOS, VM., 2004. Accumulation of paralytic shellfish toxins (PST) from the cyanobacterium Aphanizomenon issatschenkoi by cladoceran Daphnia magna. Toxicon, vol. 44, p. 773-780. PMid:15500853. http://dx.doi.org/10.1016/j.toxicon.2004.08.006

OSHIMA, Y., 1995. Postcolumn derivatization liquid chromatographic method for paralytic shellfish toxins. Journal of AOAC International, vol. 78 , p. 528-532.

POMATI, F., SACCHI, S., ROSSETTI, C., GIOVANNARDI, S., ODONERA, H., OSHIMA, Y. and NEILAN, BA., 2000. The freshwater cyanobacterium Planktothrix sp FP1: molecular identification and detection of paralytic shellfish poisoning toxins. Journal of Phycology, vol. 36, p. 553-562. http://dx.doi. org/10.1046/j.1529-8817.2000.99181.x

SIGEE, DC., 2005. Freshwater microbiology: biodiversity and dynamic interactions of microorganisms in the freshwater environment. England: John Wiley \& Sons Ltda. 17 p. Available from: <http://onlinelibrary.wiley.com/doi/10.1002/0470011254. fmatter/pdf $>$.

SOARES, MCS., DE A ROCHA, MI., MARINHO, MM., AZEVEDO, SMFO., BRANCO, CWC. and HUSZAR, VLM., 2009a. Changes in species composition during annual cyanobacterial dominance in a tropical reservoir: physical factors, nutrients and grazing effects. Aquatic Microbial Ecology, vol. 57, p. 137-149. http://dx.doi.org/10.3354/ame01336

SOARES, MCS., LURLING, M., PANOSSO, R. and HUSZAR, V., 2009b. Effects of the cyanobacterium Cylindrospermopsis raciborskii on feeding and life-history characteristics of the grazer Daphnia magna. Ecotoxicology and Environmental Safety, vol. 72, p. 1183-1189. PMid:18951629. http://dx.doi.org/10.1016/j. ecoenv.2008.09.004

STATISTICAL Package, 1997. SPSS Base 7.5 Applications Guide. Chicago: SPSS Inc. 339p.

STATSOFT Inc., 2007. Statistica (data analysis software system). version 7. Available from: <www.statsoft.com>.

TUCCI, A. and SANT'ANNA, CL., 2003. Cylindrospermopsis raciborskii (Woloszynska) Seenayya \& Subba Raju (Cyanobacteria): variação semanal e relações com fatores ambientais em um 
reservatório eutrófico, São Paulo, SP, Brasil. Revista Brasileira de Botânica, vol. 26, no. 1, p. 97-112.

YUNES, JS., CUNHA, NT., CONTE, SM., RABELLO, IM., GIORDANI, AT., BENDATTI, MM., MAIZONAVE, CM., GRANADA, GL. and HEIN, RP., 2000. Programa ÁguaAN: agilização do gerenciamento e utilização de águas com algas nocivas. In Anais do XXVII Congresso Interamericano de Engenharia Sanitária e Ambiental, 2000. Porto Alegre.

YUNES, JS., CUNHA, NT., PROENÇA, LAO., BARROS, LPC. and MONSERRAT, JM., 2003. Cyanobacterial neurotoxins from
Southern Brazilian freshwaters. Comments on Toxicology, vol. 9, p. 103 - 115. http://dx.doi.org/10.1080/08865140302426

ZAGATTO, PA., BURATINI, SV., ARAGÃO, MA. and FERRÃOFILHO, AS., 2012. Neurotoxicity of two Cylindrospermopsis raciborskii (cyanobacteria) strains to mice, Daphnia, and fish. Environmental Toxicology and Chemistry, vol. 31, p. 857-862. PMid:22278803. http://dx.doi.org/10.1002/etc.1759

ZOHARY, T. and ROBERTS, RD., 1990. Hyperscums and the population dynamics of Mycrocystis aeruginosa. Journal plankton Research, vol. 12, p. 423-432. http://dx.doi.org/10.1093/ plankt/12.2.423 